\title{
INFORMATION SYSTEM OF TUITION AND THESIS PAYMENT VERIFICATION WITH ADAPTIVE LAYOUT DESIGN
}

\author{
Bambang Adiwinoto ${ }^{1 *}$; Yohanes Setiawan Japriadi²; Lukas Tommy ${ }^{3}$ \\ Information Systems ${ }^{1}$; Informatics Engineering 2,3 \\ Atma Luhur ISB, Pangkalpinang, Indonesia \\ https://www.atmaluhur.ac.id \\ baw@atmaluhur.ac.id ${ }^{1}$; ysetiawanj@atmaluhur.ac.id ${ }^{2}$; lukastommy@atmaluhur.ac.id ${ }^{3}$ \\ $\left(^{*}\right)$ Corresponding Author
}

\begin{abstract}
The verification system of tuition and thesis payment at ISB Atma Luhur which is running is felt to be less effective and efficient because students must come directly to campus with proof of payment during working hours to verify the payment. Also, there is the possibility of negligence by the finance department that only stamped the payment slip without doing a flag, consequently, related students were unable to carry out the selection of lecture groups and thesis supervisors when the schedule began. This caused them to not get the favorite lecture groups and thesis supervisors because the quota had run out. To overcome this problem, an information system for verification of tuition payment and web-based thesis verification will be developed with an adaptive layout design so that it can be accessed by laptop or smartphone users without reducing comfort during operation. The system development model and tool used in this research are the waterfall model and the Unified Modeling Language (UML), respectively. The developed system can be used by students to upload proof of payment and monitor the verification status of proof of payment that was previously uploaded. The system can also be used by the finance department to verify payments, as well as display and print payment verification reports. The developed system can be accessed anywhere and anytime so that the efficiency and effectiveness of the verification process are increased.
\end{abstract}

Keywords: Adaptive Layout Design, Information Systems, Payment, Verification, Web.

Abstrak-Sistem verifikasi pembayaran uang kuliah dan skripsi di ISB Atma Luhur yang sedang berjalan dirasakan kurang efektif dan efisien dikarenakan mahasiswa harus datang langsung ke kampus dengan membawa bukti pembayaran pada jam kerja untuk melakukan verifikasi pembayaran. Selain itu ada kemungkinan terjadinya kelalaian oleh bagian keuangan yang hanya menstempel slip pembayaran tanpa melakukan flag, akibatnya mahasiswa terkait tidak dapat melaksanakan pemilihan kelompok perkuliahan dan dosen pembimbing skripsi ketika jadwalnya dimulai. Hal ini menyebabkan mereka tidak mendapatkan kelompok perkuliahan dan dosen pembimbing skripsi favorit karena kuotanya telah habis. Untuk mengatasi permasalahan ini, akan dikembangkan sistem informasi verifikasi pembayaran uang kuliah dan skripsi berbasis web dengan desain layout adaptif agar dapat diakses oleh pengguna laptop ataupun smartphone tanpa mengurangi kenyamanan selama pengoperasiannya. Model dan tools pengembangan sistem yang digunakan pada penelitian ini berturut-turut adalah model waterfall dan Unified Modelling Languange (UML). Sistem yang dikembangkan dapat digunakan mahasiswa untuk mengunggah bukti pembayaran dan memantau status verifikasi atas bukti pembayaran yang sebelumnya diunggah. Sistem juga dapat digunakan oleh bagian keuangan untuk memverifikasi pembayaran, sekaligus menampilkan dan mencetak laporan verifikasi pembayaran. Sistem yang dikembangkan dapat diakses di mana dan kapan saja sehingga efisiensi dan efektivitas dari proses verifikasi menjadi meningkat.

Kata Kunci: Adaptive Layout Design, Pembayaran, Sistem Informasi, Verifikasi, Web

\section{INTRODUCTION}

The development of Information and Communication Technology (ICT) is very fast, in line with the very high need for ICT (Pahrudin, 2019). With the presence of ICT will greatly help people in various fields of work, including education. The Atma Luhur Institute of Science and Business (ISB) campus is one of the private universities in the province of Bangka Belitung Island that utilizes ICT to support its daily operational activities.

Several problems make business processes in the payment verification system for tuition fees and thesis at Atma Luhur ISB become ineffective and inefficient. Students are required to meet the Academic Advisor (PA) lecturer to fill Study Plan Card (KRS) and then go to the finance department to make a tuition payment slip. 
The student then makes a payment at the bank with proof of payment in the form of a stamp from the bank. Students can also make payments by transfer and then bring the proof of payment to the finance department to be verified using a desktop system which connected to the Local Area Network (LAN).

The above payment verification process requires students to come to campus so that their payments can be flagged (Rafika et al., 2017). This is not effective because not all students are located close to campus. Besides, the payment verification is done manually (Sutoyo, 2020) by the finance department, i.e. by stamping the proof of payment (Dedi et al., 2019). This makes human error possible (Nuryamin \& Budi, 2020) where the finance department sometimes does not immediately enter student payment transactions that have been stamped into the system (Dharmawan et al., 2018). As a result, students are at risk of being late in choosing course groups taught by their favorite lecturers so that it has an impact on that student's academic performance. It is the same with thesis registration where there is a limitation on guidance quota for each lecturer.

Based on the problems described above, an adaptive web-based information system will be developed to verify the payment of tuition fees and the thesis. The layout of the web that is designed to be adaptive will be adjusted automatically based on the device (mobile or laptop) used by the user (Gustafson, 2015). The adaptive web is more suitable to be applied than Android because there are quite a several students at ISB Atma Luhur still use laptops, some even use iPhones. Also, the web system can be accessed not only with computers but also with a smartphone browser, so that developers can more focus and easier on developing systems. It is different if an Android application is developed which cannot be accessed with a computer (Solichin, 2016) or smartphone other than Android (Tommy et al., 2019).

Previous studies on payment verification information systems have been conducted. The implementation of a Midtrans-based payment gateway as a payment verification system on the website for hosting sales and the iPanda domain makes the existing payment system easier, more convenient, well-documented, and efficient (Febriyanto et al., 2018). There is also the development of a payment verification application using a web scraping method to facilitate new student admissions (PMB) process. The payment verification process is carried out automatically by application by checking payment transactions that enter bank account (Mulyana \& Savitri, 2015). Rahardja, et al. implements the $\mathrm{GO}+$ payment system (go-plus) in the academic information system of Raharja College for online payment confirmation menu form that makes it easy for the financial department to check incoming transactions and improve services to students (Rahardja et al., 2017).

There are also previous studies that discuss web design including Cazanas and Parra (Cazanas \& Parra, 2017) which compares and analyzes responsive, adaptive, and separate web design where adaptive is stated to be the most superior. Adaptive designs are easier to maintain and implement while adding the ability to customize content and navigation for specific devices. Hidayat, et al applies responsive web design to the learning system. The system display is adjusted according to the size of the browser window, but it is not optimal when accessed with a smartphone because some interface elements are not positioned correctly (Hidayat et al., 2016). Novianty reviews responsive design on websites that can adjust its display size even though the user experience is reduced when accessed with mobile devices (Novianty, 2019).

Unlike the previous studies which only reviewed the layout design (Cazanas \& Parra, 2017; Novianty, 2019) and implement responsive web design (Hidayat et al., 2016), in this research an adaptive design will be applied to the web using the WordPress framework where user experience does not decrease even though the system is accessed with a smartphone (Gustafson, 2015). This is because in WordPress there are various screen layout settings where the most appropriate one will be automatically selected based on the screen resolution of the device that is accessing it so that interface elements remain organized. This system later can be used by students to upload payment proof of tuition or thesis registration fees with smartphones or desktop without having to come directly to campus so that the required time and transportation costs are reduced. Also, the possibility of human error in the payment receipt flag can be reduced because the status of student payments that have been uploaded can be known by a related student or finance department.

\section{MATERIALS AND METHODS}

\section{A. System Development Model}

The waterfall system development model is used in this research to provides a software life flow approach sequentially (Hardiyanto et al., 2019).

1. Software Requirements Analysis

In this step, interviews with related parties, i.e. financial department and student to determine business processes that occur as well as to identify the system functional requirements of each user. 


\section{Design}

This step includes modeling the running system with activity diagrams, grouping system usage with use case diagrams from the user side, database modeling with class diagrams, designing system interfaces, through making sequence diagrams to describe the processes that exist on each page.

3. Code Generation

The design from the previous step then is coded into appropriate web programming languages, i.e. HyperText Markup Language (HTML), Cascading Style Sheets (CSS), JavaScript, and PHP: Hypertext Preprocessor (PHP). The framework used in this research is WordPress which supports adaptive web display design where its display will be adjusted automatically based on the user's device. As the source code editor and relational database management system used respectively are Sublime Text and MySQL.

\section{4. $\quad$ Testing}

The testing step will be carried out by testing the whole system using the black-box testing model. At first, testing is done by the developer to find and fix errors. The system is then tested again by students and the finance department to find out whether the system has met their needs in form of a questionnaire that is distributed to 125 respondents.

5. Support

Support will still be provided after the tuition and thesis payments verification system is implemented on the Atma Luhur ISB server and website, such as in terms of error fixing, adding features, and system configuration so that it can adapt to a new environment.

\section{B. Data Collection Technique}

The data collection techniques used in this study were literature study, interviews, and observation.

\section{Literature Study}

The literature related to the concept and work procedure of the verification information system that has been done by previous researchers was studied before conducting this research. The references used are books and scientific articles related to the verification information system. In general, the existence of a verification information system can make it easier for users to support business processes that occur more effectively and efficiently.

\section{Interview}

Information about the business processes that occur in the payment verification system for student's tuition and theses fees, from KRS entry to flags of payment transactions that are conducted will be collected first. The question and answer process to related parties, i.e. students and the finance department will be carried out to obtain information such as functional and non-functional requirements of the payment verification system that will be developed. It is also known that most of Atma Luhur ISB students use smartphones when accessing student academic web so that a payment verification system will be developed which can also reach smartphone users.

\section{Observation}

In this observation technique, data is collected by making direct observations on the verification process of tuition and thesis payments in the finance department to look for existing problems. As for the solution that can be offered in this research is to develop a web-based system that can be used by the finance department and students to support the verification process of tuition and thesis payments which is more effective and efficient than the current system.

\section{RESULTS AND DISCUSSION}

\section{A. Requirements Analysis}

Based on interviews that have been conducted with students and the finance department, the running system process as well as functional requirements of the proposed system can be analyzed. The process of verifying proof of tuition fees and thesis payment that runs at Atma Luhur ISB is as shown in Figure 1. First of all, students who have made payments come to campus to hand overslips and proof of payment to the finance department.

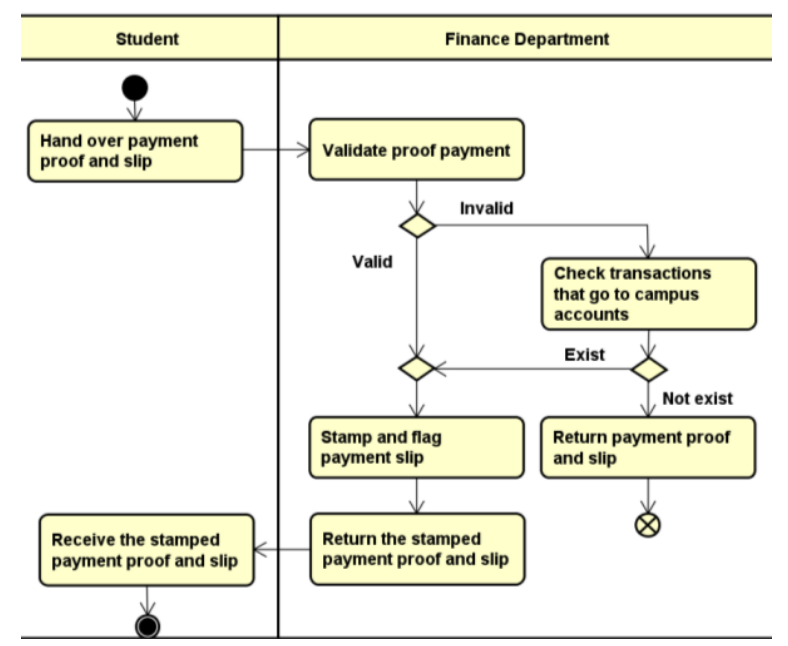

Source: (Adiwinoto et al., 2019)

Figure 1. The Running System Activity Diagram

The finance department then validates that payment proof. If it is not valid, the transaction history that goes to the campus account will be checked and if exist, the next stage will be carried out, and if there is not, that payment proof will be 
returned to the student. If valid, the finance department will stamp that payment slip and flag it using a desktop-based information system. After that, the stamped payment proof and slip will be returned to the student and that student can choose course groups or thesis supervisors according to a predetermined schedule.

By using the proposed system, students can upload payment proof of tuition fees and theses as well as checks the status of that payment proof whether it has been flagged or not by the finance department without having to come to campus at the specified time. The finance department can also verify and check payment lists uploaded by students even when not on campus and outside of working hours if needed by using the proposed system. Also, the system must still comfortable when operated with a smartphone.

\section{B. Design}

The design made in developing tuition and thesis payment verification system, i.e. the relationship between actors and existing system are designed using use case diagrams, the representation of system behavior using activity diagrams and sequence diagrams, whereas the classes of the system are represented using class diagrams.

1. Use Case Diagram

Figure 2 shows the use case diagram of the proposed tuition and thesis payment verification system. In addition to student and finance department users, there is also admin who can manage users, finance staff, students, estimation (payment details), and payment slips data.

2. Activity Diagram

In this paper, only 3 activity diagrams will be displayed due to page limitations. Upload proof of payment, view payment verification status, and payments verification activity diagrams respectively can be seen in Figure 3, Figure 4, and Figure 5.

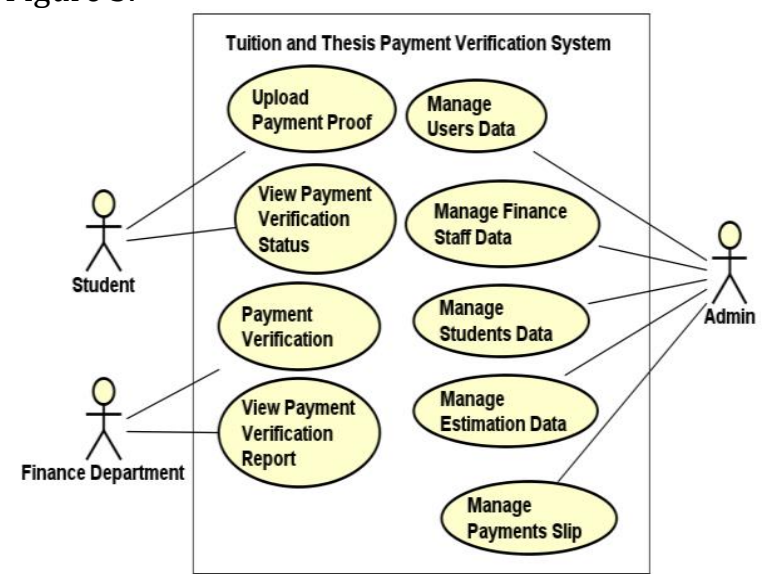

Source: (Adiwinoto et al., 2019)

Figure 2. The Proposed System Use Case Diagram

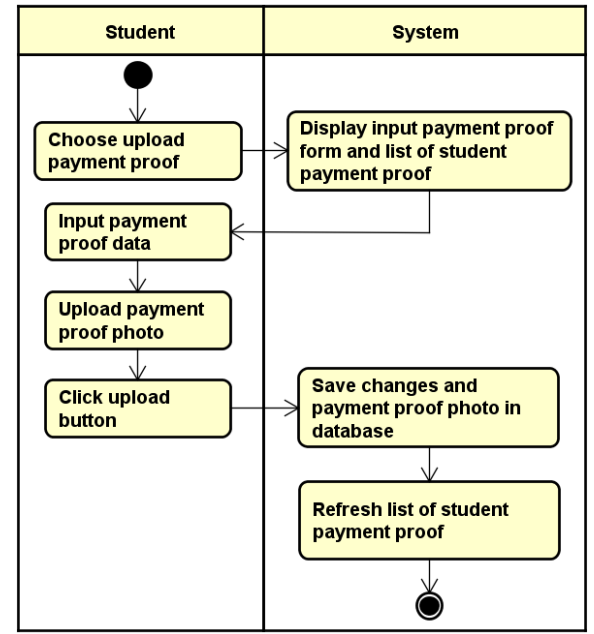

Source: (Adiwinoto et al., 2019)

Figure 3. The Upload Payment Proof Activity Diagram

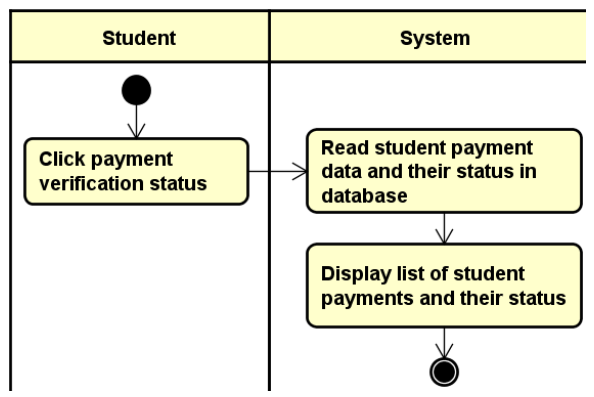

Source: (Adiwinoto et al., 2019)

Figure 4. The View Payment Status Activity Diagram

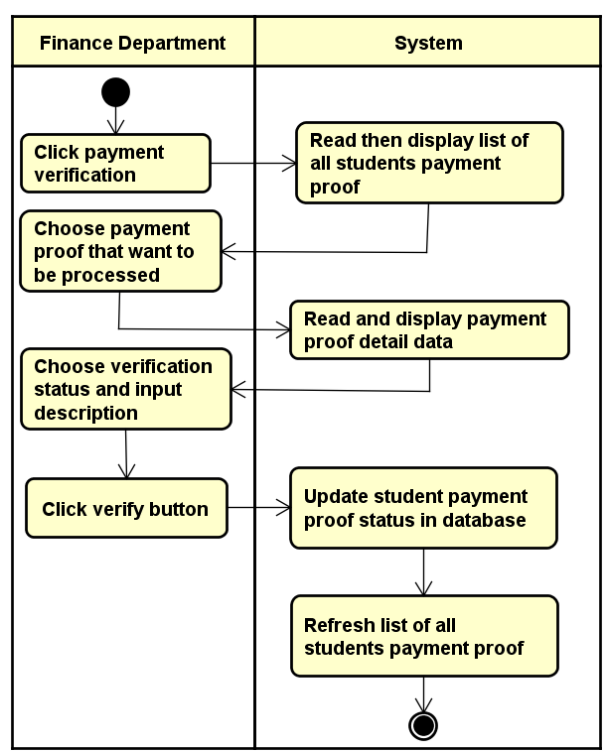

Source: (Adiwinoto et al., 2019)

Figure 5. The Payment Verification Activity Diagram

3. Sequence Diagram

The sequence diagram for upload payment proof, view payment verification status, and 
payment verification respectively is shown in Figure 6, Figure 7, and Figure 8.

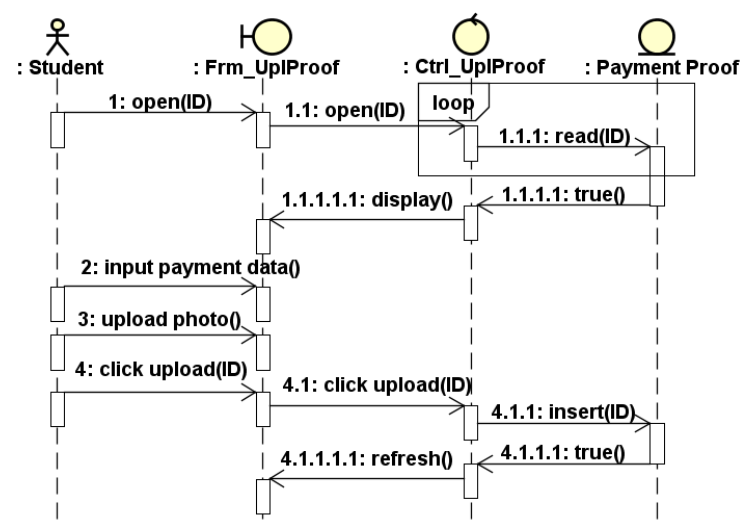

Source: (Adiwinoto et al., 2019)

Figure 6. The Upload Payment Proof Sequence Diagram

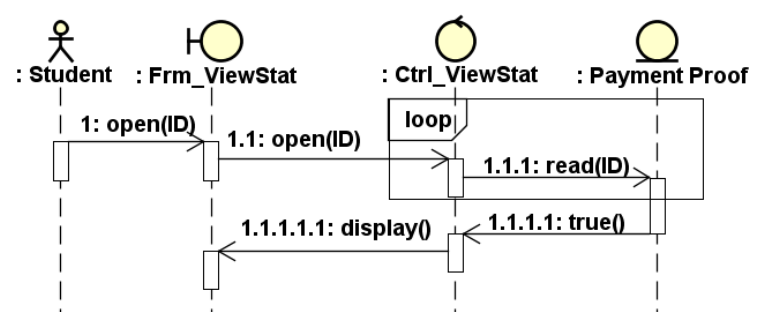

Source: (Adiwinoto et al., 2019)

Figure 7. The View Payment Status Sequence Diagram

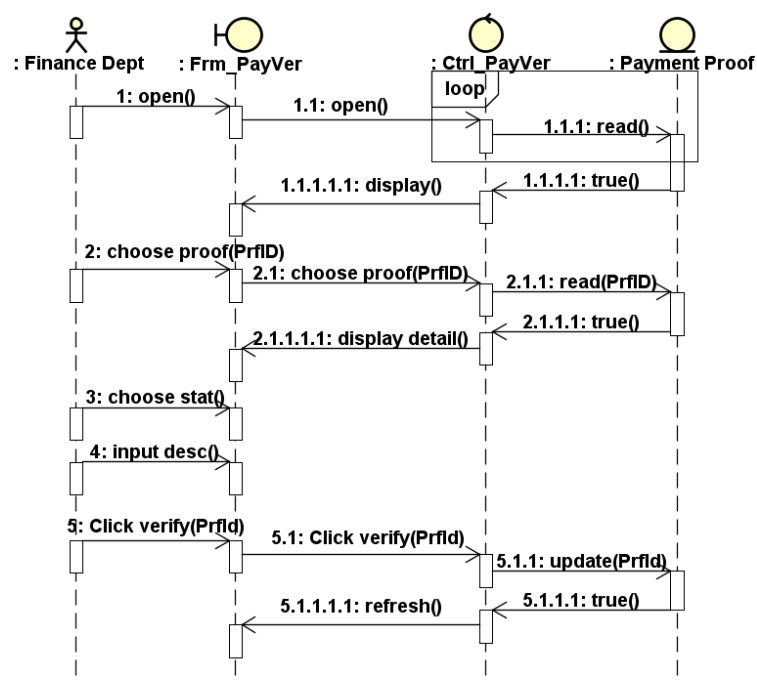

Source: (Adiwinoto et al., 2019)

Figure 8. The Payment Verification Sequence Diagram

\section{Class Diagram}

The class diagram of the proposed tuition and thesis payment verification system can be seen in Figure 9 where there are also Wp_usermeta and Wp_user tables because the web developed uses
WordPress to manage its content, such as user management.

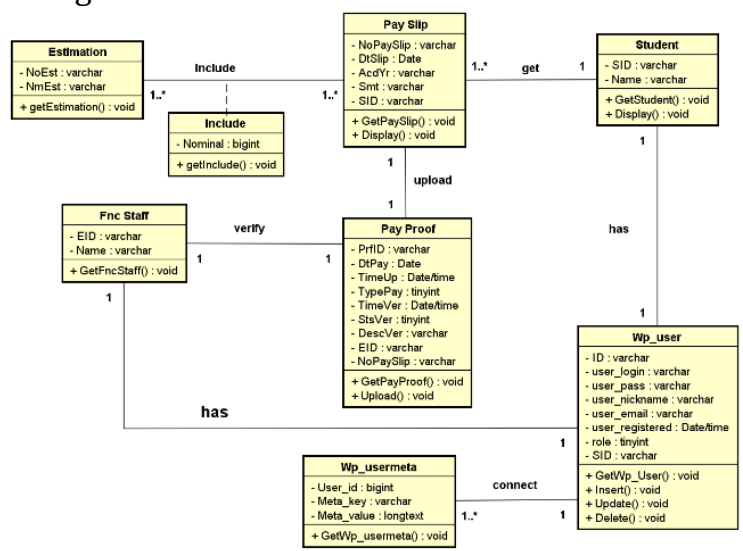

Source: (Adiwinoto et al., 2019)

Figure 9. The Proposed System Class Diagram

\section{Code Generation}

Here is one of code snippets from proposed system for upload payment proof.

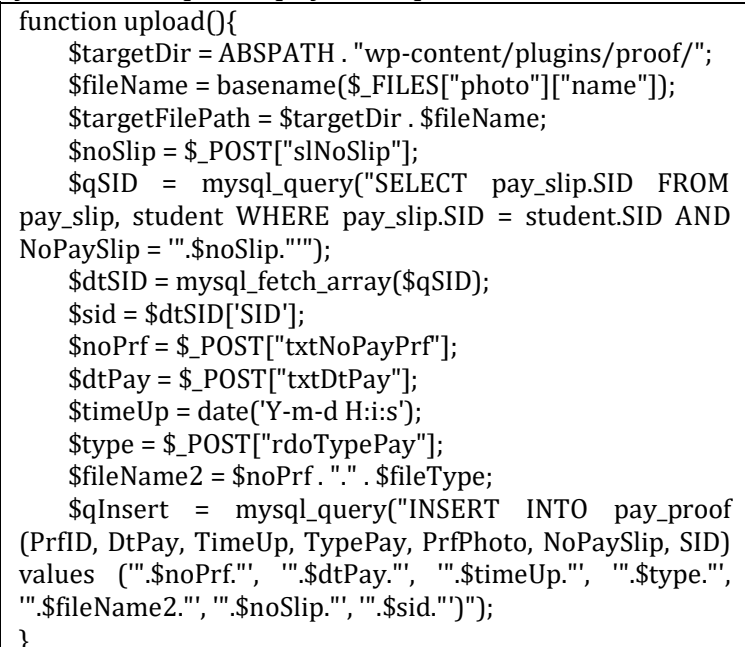

\section{Testing}

The black box testing model is used to test the functionality of the developed system and the Likert scale is used to measure the level of respondents' agreement of the proposed system. The results of black-box testing that have been carried out (not shown in this paper) on the developed system are all of its functionalities by the expected results whether accessed with a laptop or smartphone.

The recapitulation of the questionnaire measured by Likert scale and distributed to 125 respondents (finance department, students, and PA lecturers) associated with the developed system is as shown in Table 1. The Likert scale is a research scale to measure the attitudes and opinions of respondents who are asked to complete a questionnaire to show their level of agreement with several questions. Based on the recapitulated 
questionnaire, overall respondents agreed to the points asked in the questionnaire with an average value of $84.12 \%$. This percentage is obtained using equation (1).

Table 1. The Results of Questionnaire Recapitulation

\begin{tabular}{|c|c|c|c|c|c|c|}
\hline No & Questions & $\begin{array}{c}1 \\
\text { (D) }\end{array}$ & $\begin{array}{c}2 \\
\text { (LA) }\end{array}$ & $\begin{array}{c}3 \\
\text { (A) } \\
\end{array}$ & $\begin{array}{c}4 \\
\text { (SA) } \\
\end{array}$ & $\begin{array}{l}\text { AVG } \\
(\%) \\
\end{array}$ \\
\hline 1 & $\begin{array}{l}\text { The system } \\
\text { facilitates the } \\
\text { process of } \\
\text { uploading tuition } \\
\text { and theses fees } \\
\text { payment proof as } \\
\text { well as monitoring } \\
\text { their verification } \\
\text { status }\end{array}$ & 4 & 7 & 46 & 68 & 85,6 \\
\hline 2 & $\begin{array}{l}\text { The system } \\
\text { facilitates the } \\
\text { process of verifying } \\
\text { student payment } \\
\text { proof by the finance } \\
\text { department }\end{array}$ & 3 & 5 & 41 & 76 & 88 \\
\hline 3 & $\begin{array}{l}\text { The system reduces } \\
\text { the possibility of } \\
\text { human error in the } \\
\text { process of payment } \\
\text { proof flag }\end{array}$ & 5 & 9 & 59 & 52 & 81,6 \\
\hline 4 & $\begin{array}{l}\text { The system can } \\
\text { display information } \\
\text { related to payment } \\
\text { proof }\end{array}$ & 4 & 7 & 43 & 71 & 86,2 \\
\hline 5 & $\begin{array}{l}\text { The system is easy } \\
\text { and comfortable to } \\
\text { use when operated } \\
\text { with a smartphone }\end{array}$ & 7 & 13 & 57 & 48 & 79,2 \\
\hline & Total Average & 23 & 41 & 246 & 315 & 84,12 \\
\hline
\end{tabular}

Source: (Adiwinoto et al., 2019)

Description : D : Disagree, LA : Less Agree, A : Agree, SA : Strongly Agree, AVG\% : Average Percentage

\section{The Frequency of Human Errors in} Finance Department per Month

- Running System $\quad$ Proposed System

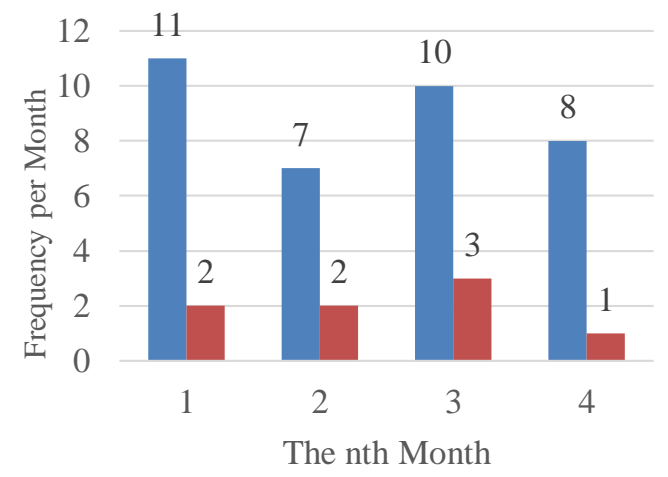

Source: (Adiwinoto et al., 2019)

Figure 10. The Finance Department Human-Error Comparison Chart per Month

$$
\begin{aligned}
& \% \text { average agreement } \\
& =\frac{\sum \text { total weight of questionnaire }}{\text { num. of respondents } \times \text { num. of questions } \times 4} \times 100 \% \\
& =\frac{(23 \times 1)+(41 \times 2)+(246 \times 3)+(315 \times 4)}{2500} \times 100 \% \\
& =84,12 \%
\end{aligned}
$$

Figure 10 shows a comparison graph between the running finance system and the proposed system in terms of the number of human errors related to payment flags in the finance department in one month. It can be seen that the frequency of this human error can be reduced significantly by uses the proposed system in the last four months (October 2019 to January 2020) when compared to the previous four months (until September 2019) which still uses existing desktopbased finance system.

\section{E. Support}

Some screen display of the payment verification system that has been implemented is as follows:

1. The Payment Proof Upload Page

Figure 11 is the display of the payment proof upload page if the user accesses it with desktop where on this page students can upload photos or screenshots of payment proof for tuition or thesis fees that have been done by payment slip number. Figure 12 is the display of the payment proof upload page if the user accesses it with a mobile device. It appears that on smartphones the system display will adjust to that smartphone screen size.

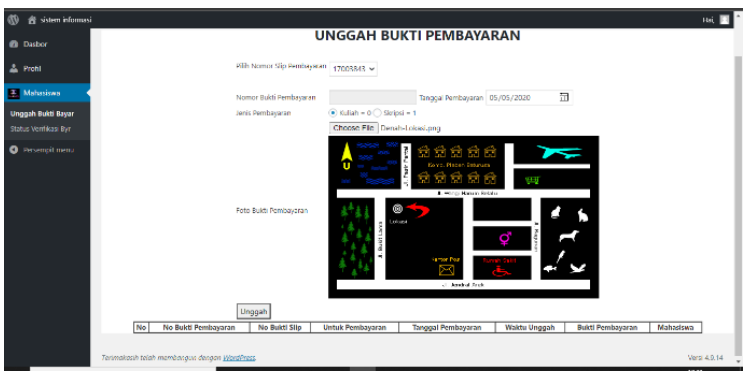

Source: (Adiwinoto et al., 2019)

Figure 11. The Payment Proof Upload Page on Desktop

2. The Payment Verification Status Page

Figure 13 is the display of the payment verification status page where on this page students can find out the status of payment proof that they have previously uploaded whether it is failed, in process, or successfully verified.

\section{The Payment Verification Page}

Figure 14 is the display of the payment verification page where on this page finance department can find out the details of payment 
proofs that are uploaded by students and change their verification status.

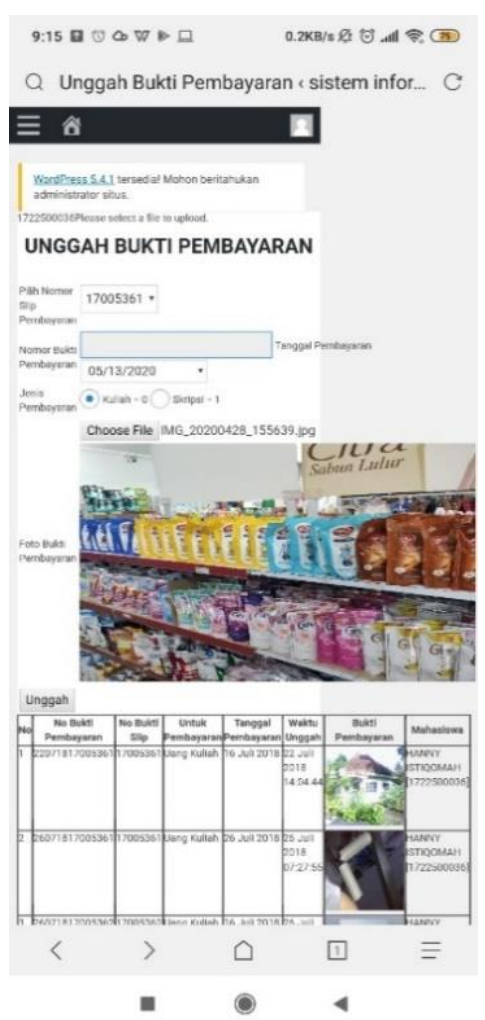

Source: (Adiwinoto et al., 2019)

Figure 12. The Payment Proof Upload Page on Mobile

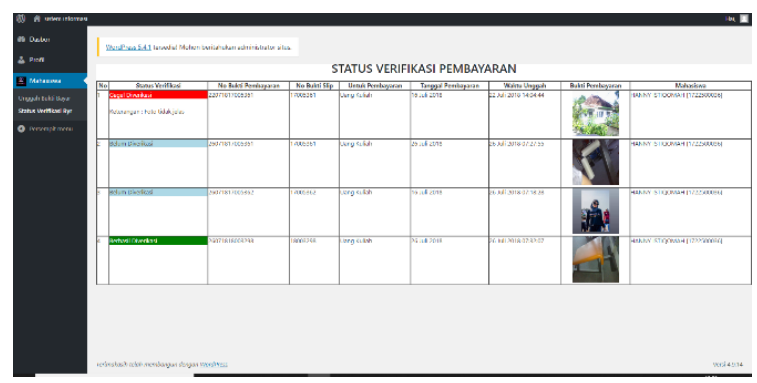

Source: (Adiwinoto et al., 2019)

Figure 13. The Payment Verification Status Page

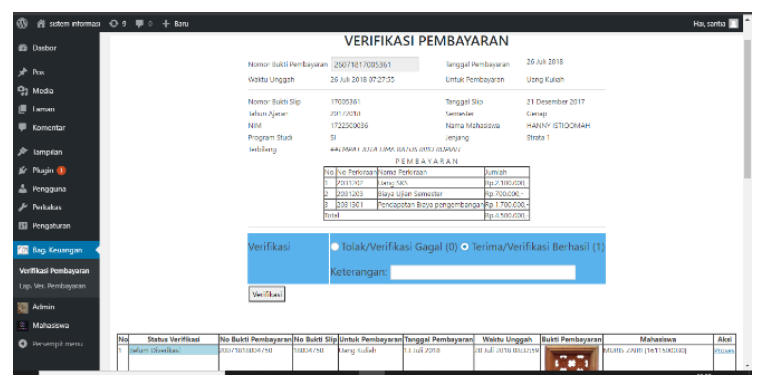

Source: (Adiwinoto et al., 2019)

Figure 14. The Payment Verification Page
4. The Payment Verification Reports Page

Figure 15 is the display of the payment verification report page where on this page finance department can find out the reports of all payment proofs which are uploaded by students along with verification status and who verifies it. Also, this payment verification report can be printed.

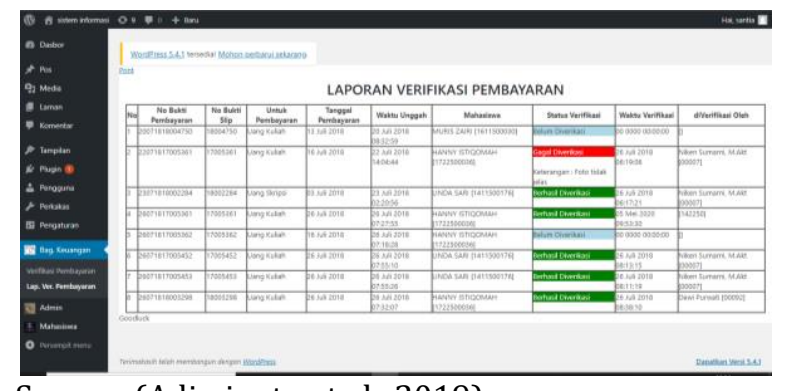

Source: (Adiwinoto et al., 2019)

Figure 15. The Payment Verification Reports Page

\section{CONCLUSION}

The development of web-based tuition and thesis fee payment verification information system with an adaptive layout design on Atma Luhur ISB can overcome problems that exist in the running system. The developed system can be used by laptop even mobile users without reducing comfort when using it because its layout is designed to be adaptive. This system can also facilitate students to upload payment proof as well as monitor their verification status without having to come to campus during working hours. In addition, this system facilitates finance department to verify student payment proof as well as reduce the possibility of human error when flagging payment proof because finance department can easily find out payment proof that has not been verified.

In the future, this system can be improved by integrating payment gateways or web scraping so that the verification process can be carried out automatically by system based on transfer of money that go to campus accounts without requiring students to upload payment proof.

\section{REFERENSI}

Adiwinoto, B., Japriadi, Y. S., \& Tommy, L. (2019). Laporan Akhir Penelitian Sistem Informasi Verifikasi Pembayaran Uang Kuliah dan Skripsi Mahasiswa STMIK Atma Luhur dengan Adaptive Layout Design.

Cazanas, A., \& Parra, E. (2017). Strategies for Mobile Web Design. Enfoque UTE, 8(1), 344357.

Dedi, Mariana, A. R., \& Susanto, E. A. E. (2019). 
Perancangan Sistem Informasi Pengelolaan Administrasi Pendapatan Keuangan Studi Kasus STMIK Bina Sarana Global. Jurnal Sisfotek Global, 9(1), 1-7.

Dharmawan, W. S., Purwaningtias, D., \& Risdiansyah, D. (2018). Penerapan Metode SDLC Waterfall Dalam Perancangan Sistem Informasi Administrasi Keuangan Berbasis Desktop. Jurnal Khatulistiwa Informatika, 6(2), 159-167.

Febriyanto, E., Rahardja, U., \& Alnabawi, N. (2018). Penerapan Midtrans sebagai Sistem Verifikasi Pembayaran pada Website iPanda. Jurnal Informatika UPGRIS, 4(2), 246-254.

Gustafson, A. (2015). Adaptive Web Design: Crafting Rich Experiences with Progressive Enhancement (2nd ed.). Pearson Education.

Hardiyanto, Abdussomad, Haryadi, E., Sopandi, R., \& Asep. (2019). Penerapan Model Waterfall dan UML Dalam Rancang Bangun Program Pembelian Barang Berorientasi Objek pada PT. Fujita Indonesia. Jurnal Interkom, 13(4), 4-11.

Hidayat, A., Utomo, V. G., \& Djohan, H. A. (2016). Penerapan Responsive Web Design dalam Perancangan Sistem Modul Online Adaptif. Journal of Information System, 12(1), 44-48.

Mulyana, Y., \& Savitri, P. (2015). Pembuatan Aplikasi Verifikasi Pembayaran dengan Metode Web Scraping pada Pengembangan Aplikasi Penerimaan Mahasiswa Baru (Studi Kasus: Politeknik Manufaktur Negeri Bandung). Jurnal Manajemen Informatika (JAMIKA), 5(2), 29-42.

Novianty, C. (2019). Review konsep responsive
Design dengan Framework Materialize pada Website. InfoTekJar (Jurnal Nasional Informatika Dan Teknologi Jaringan), 2(1), 41-44.

Nuryamin, Y., \& Budi, E. S. (2020). Perancangan Program Administrasi Pembayaran SPP, UTS dan UAS Pada MA Al-Marzukiyah Jakarta. Jurnal Sistem Komputer Dan Informatika (JSON), 1(2), 77. https://doi.org/10.30865/json.v1i2.1852

Pahrudin, P. (2019). Etika Profesi Komputer. Goresan Pena Kuningan.

Rafika, A. S., Putri, D. I., \& Sanusi, S. (2017). Sistem Pembayaran Rincian Biaya Kuliah Pada Perguruan Tinggi Raharja Menggunakan Go+. Journal CERITA, 3(1), 64-74.

Rahardja, U., Aini, Q., \& Thalia, M. B. (2017). Penerapan Menu Konfirmasi Pembayaran Online Berbasis Yii pada Perguruan Tinggi. Creative Information Technology (CITEC) Journal, 4(3), 174-185.

Solichin, A. (2016). Pemrograman web dengan PHP dan MySQL. Penerbit Budi Luhur.

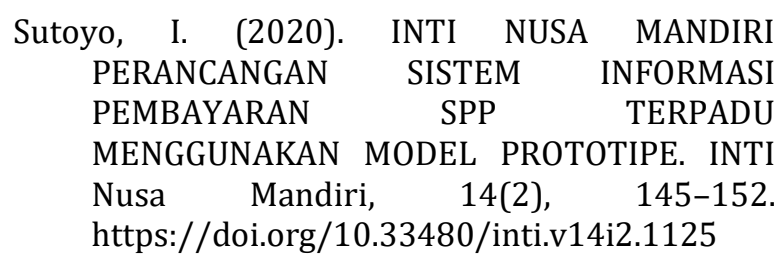

Tommy, L., Kirana, C., \& Lindawati, V. (2019). Recommender System dengan Kombinasi Apriori dan Content-Based Filtering pada Aplikasi Pemesanan Produk. Jurnal Teknoinfo, 13(2), 84-95. 